\title{
Inheritance of agronomic and seed composition traits in Glycine max x Glycine soja crosses ${ }^{1,2}$
}

\author{
Sylvia Rodriguez de Cianzio ${ }^{3}$ and Walter R. Fehr ${ }^{4}$
}

\begin{abstract}
Interspecific crosses between the cultivated soybean, Glycine max (L.) Merr., and the wild species, Glycine sojaSieb. \& Zucc. may be useful for broadening the genetic base of commercial cultivars. The objectives of the study were to evaluate agronomic traits of $G$. max, $G$. soja and their $F_{1}$ hybrids in tropical and temperate environments, to determine whether cytoplasmic effects were present for agronomic traits and seed composition in reciprocal crosses between the two species, and to evaluate the type of gene action that controls the inheritance of traits in interspecific crosses. Reciprocal crosses were made between 'Century' and PI326581 and between 'Amsoy 71 ' and PI424001. Thirty plants of each of the parents and $50 \mathrm{~F}_{1}$ plants of each cross were grown at two environments in Puerto Rico and one in lowa. The traits evaluated were date of stages R 1 and RB, leaf size, shattering, defoliation, vining, lodging, agronomic type, plant height, 100 -seed weight, percentage of seed protein and oil, and percentages of palmitic, stearic, oleic, linoleic, and linolenic acids in the oil. No significant differences were observed among environments for seven of the 11 agronomic traits evaluated in the two crosses. The relative performance among genotypes for all traits in lowa and Puerto Rico was similar. This similarify indicates that it is possible to use tropical locations to evaluate the progeny of interspecific crosses. No significant differences between $F_{1}$ plants of reciprocal crosses were observed in the iwo crosses for any of the traits; thus; cytoplasmic effects were not important. The fype of gene action observed differed among traits and included additive, dominance, and partial dominance.
\end{abstract}

\section{INTRODUCTION}

Interspecific crosses between Glycine max (L.) Merr. and G. soja Sieb. \& Zucc. may be useful for broadening the genetic base of commercial cultivars. Harlan and De Wet (7) included the two species as part of the primary gene pool of the domesticated soybean. Both species make up the subgenus Soja, and have been hybridized successfully by artificial cross-pollination $(6,12,13,14)$. Partial sterility in some crosses between these two species has been reported $(1,14)$.

'Manuscript submitted to Editorial Board May 14, 1986.

Joint contribution from the Iowa Agricultural and Home Economics Experiment Station, Ames, Iowa, Project No. 2475, Journal Paper No. J-11841; and the Agricultural Experiment Station, Mayaguez, Puerto Rieo. The research was supported in part by grants from the Iowa Soybean Promotion Board and the U. S. Department of Agriculture.

"Associate professor, Department of Agronomy, Iowa State University, and Department of Agronomy and Soils, University of Puerto Rico, Mayagüez, P. R. 00708.

IProfessor, Department of Agronomy, lowa State University, Ames, IA 50011. 
Tropical and temperate environments have been compared for their usefulness in selecting soybean genotypes that are adapted to the northern United States. It has been found that seed size $(2,4)$, protein and oil content (3), and fatty acid compostion (8) can be effectively selected in tropical conditions. There is no published information, however, on the evaluation of other agronomic traits in tropical locations. The first objective of our study was to evaluate agronomic traits of Glycine max and $G$. soja genotypes and their $\mathbf{F}_{1}$ hybrids in tropical and temperate environments.

The strategy for germplasm introgression from $G$. soja to $G$. max will be determined by the mode of inheritance of desirable and undesirable characters in interspecific crosses. One consideration is the presence of cytoplasmic effects, and another is the type of gene action that controls a character. Cytoplasmically-inherited traits are known to occur in $G$. max. Terao (11) described a cytoplasmically inherited mutant of $G$. max, cyt-G1, which controlled green cotyledon and seed coat. There have been two reports of cytoplasmic mutants of $G$. max affecting chlorophyll levels in foliage $(9,10)$. The only study of cytoplasmic effects in interspecific crosses of $G$. mox and $G$. soja was reported by Weber (13). He studied the inheritance of seed size, maturity date, protein percentage, and iodine number of oil in a cross between the cultivar 'Dunfield' and the $G$. soja accession PI65549. The space-planted $\mathrm{F}_{2}$ population was grown with the parents and $F_{1}$ hybrids in one location in 1940 . Weber (13) did not find cytoplasmic effects for any of the four traits. A second objective of our study was to expand the evaluation of cytoplasmic effects in reciprocal crosses between $G$. max and $G$. soja to include traits not considered by Weber (13).

The type of gene action that controls some agronomic and chemical traits in interspecific crosses between $G$. max and $G$. soja has been reported $(6,12,13,14)$. Fukuda (6) reported on the inheritance of seed size in one cross of $G$. $\max \times G$. soja. Ting (12) studied the inheritance of pubescence tip; seed hardness, size and shape; seed coat color; defective seed coat; plant height; and growth habit in one cross. Williams (14) evaluated the inheritance of seed size, oil and protein percentage, growth habit, and maturity in 15 interspecific crosses. Additive gene action was found for seed size, growth habit, maturity date, oil pereentage of the seed, and iodine number of oil $(6,12,13,14)$. Dominance of the $G$. soja parent was reported for growth habit, protein percentage, and vining (14). Partial dominance of the wild parent was found for plant height, seed size, and protein percentage $(12,13)$. The third objective of our study involved the evaluation of the type of gene action for 18 traits related to agronomic performance and seed composition of progeny from G. $\max \times$ x $G$. soja crosses. 


\section{MATERIALS AND METHODS}

Two G. soja accessions from the USSR, PI326581 and PI424001, were crossed with two cultivars of G. max of Maturity Group I1, 'Century' and 'Amsoy 71'. The two $G$. soja plant introductions were randomly selected among 20 plant introductions that produced completely fertile $F_{1}$ plants when crossed to cultivars of $G$. $\max ^{5}$. Reciprocal crosses between Century and PI326581 and between Amsoy 71 and PI424001 were obtained in the greenhouse in the summer of 1980 at Ames, IA. A minimum of 50 $F_{1}$ seeds were obtained for each cross.

The parents and $F_{1}$ generation were grown at three environments in 1981. Two environments were at the Iowa State University-University of Puerto Rico Soybean Breeding Nursery at Isabela, Puerto Rico, and the third environment was at the Agronomy Research Center near Ames, lowa. Plantings in Puerto Rico were 15 January 1981 under lighted conditions and 1 November 1981 under natural day length (unlighted). In the lighted environment, plants were exposed to continuous light for a period of 15 days after emergence, followed by 14.5 -hour days until flowering was completed, then natural day length until they reached maturity. The planting date in Iowa was 29 May 1981. Thirty plants of each of the parents and $50 \mathrm{~F}_{1}$ plants of each cross were evaluated in the three environments. In the plantings of January 1981 in Puerto Rico and May 1981 in Iowa, $80 \mathrm{~F}_{2}$ hybrid plants were also evaluated. Plots consisted of single-plant hills sown in a grid of $1 \times 1 \mathrm{~m}$.

The traits evaluated for each plant at every environment were date of stages R1, beginning bloom, and R8, full maturity (5), leaf size, shattering, defoliation, lodging, and agronomic type. Plant height and vining were evaluated for each plant at the Iowa and Puerto Rico unlighted environments. Leaf size was recorded to the nearest $\mathrm{mm}$ as the average length and width of the terminal leaflet of the first three fully developed leaves on the main stem at R1. Leaf length was the distance from the petiolule insertion to the tip of the leaflet, and width was measured perpendicular to length at the widest part of the terminal leaflet. Plant height in em was measured from the soil surface to the terminal node on the main stem. On plants with no prominent main stem, leaf size and plant height were measured on the stem where the unifoliolate node was evident after the vines were separated. Shattering was rated as $1=$ shattering and $2=$ no shattering. Defoliation scores were $1=$ complete leaf loss at maturity and $2=$ no defoliation. Vining was scored as $1=$ main stem prominent, $2=$ intermediate, and $3=$ no apparent main stem. Lodging was recorded on a scale from $1=$ plant exect to $5=$ plant prostrate. Agronomic type was scored on the basis of the general appear- 
ance of plants on a seale from $1=$ highly desirable to $5=$ undesirable. All scores were assigned to the nearest 0.1 .

Seed composition and 100 -seed weight were evaluated for plants of the parents and $F_{1}$ generation. Protein and oil percentage were measured with an infrared analyzer at the USDA Northem Regional Research Center, Peoria, IL. All percentages are reported on a dry-weight basis. Fatty acid composition was determined by the Department of Food Technology at Iowa State University, as outlined by Hawkins et al. (8).

Analyses of variance combined across environments were calculated independently for each of the two crosses. Environments and genotypes were considered random effects. Means of the parents, $F_{1}$, and $F_{2}$ generations were compared by $t$-tests to assess the type of gene action controlling each trait.

\section{RESULTS AND DISCUSSION}

No significant differences were observed among environments for seven of the 11 agronomic traits evaluated in the two crosses, including lodging, defoliation, shattering, vining, agronomic type, seed weight (data not shown), and plant height (tables 1 and 2). For seed composition and fatty acid content, no significant differences among environments were observed in the two crosses (data not shown). These results indicated that the average expression of these traits for all genotypes in the three environments was similar.

The genotype $\mathrm{x}$ environment interaction was significant for all agronomic traits, except defoliation and shattering of both crosses, and for the agronomic type in the cross Amsoy $71 \times$ PI424001. For the seed composition traits and fatty acids, significant genotype $\mathrm{x}$ environment interactions were also observed for all characters of both crosses, except for protein percentage of Century $x$ PI326581. In spite of the significant genotype $\mathrm{x}$ environment interactions, the relative performance among genotypes for all traits in Iowa and Puerto Rico was similar (tables 1 and 2). These observations are in agreement with results previously reported $(2,3,4,8)$.

Significant differences between the two parents of each cross were observed for number of days to R8, lodging, shattering, vining, agronomic type, seed weight, and leaf length and width (tables 3 and 4). Amsoy 71 was also significantly different from PI424001 for number of days to R1 and defoliation. For the fatty acid and seed composition traits, significant differences between the two parents were found for the percentages of oleic and linolenic acids, and protein and oil (tables 3 and 4). In addition, Amsoy 71 differed significantly from the PI parent for the percentages of palmitic and linoleic acids.

No cytoplasmic effects were observed in the two crosses for any of the traits for which the parents differed significantly (tables 3 and 4 ). 
TABLE 1.-Agronomic performance of Century and PI326581, and their $F_{1}$ hybrids in three environments

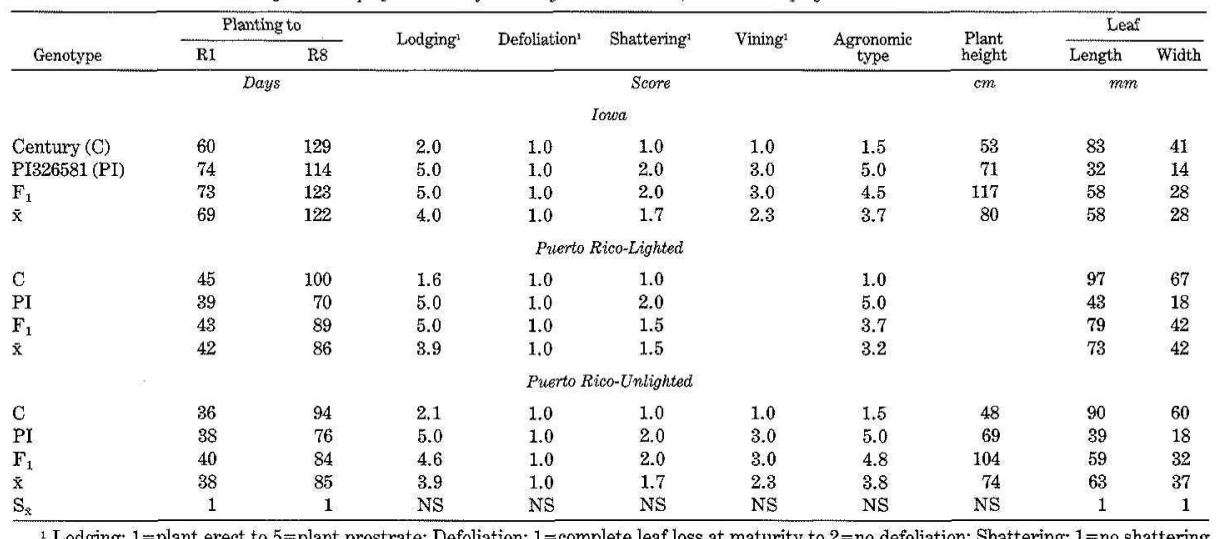

${ }_{1}^{1}$ Lodging: 1=plant erect to 5 =plant prostrate; Defoliation: $1=$ complete leaf loss at maturity to $2=$ no defoliation; Shattering: $1=$ no shattering to $2=$ shattering; Vining: $1=$ main stem prominent to $3=$ no apparent main stem; Agronomic type: $1=$ highly desirable to $5=$ undesirable. 
TABLE 2.-Agronomic performance of Amsoy 71 and PI424001, and their $F_{1}$ hybrids in three environments

\begin{tabular}{|c|c|c|c|c|c|c|c|c|c|c|}
\hline \multirow[b]{2}{*}{ Genotype } & \multicolumn{2}{|c|}{ Planting to } & \multirow{2}{*}{ Lodging $^{2}$} & \multirow{2}{*}{ Defoliation ${ }^{3}$} & \multirow{2}{*}{ Shattering ${ }^{1}$} & \multirow{2}{*}{ Vining: } & \multirow{2}{*}{$\begin{array}{c}\text { Agronomict } \\
\text { type }\end{array}$} & \multirow{2}{*}{$\begin{array}{l}\text { Plant } \\
\text { height }\end{array}$} & \multicolumn{2}{|c|}{ Leaf } \\
\hline & $\mathrm{R} 1$ & R8 & & & & & & & Length & Width \\
\hline & \multicolumn{2}{|c|}{ Days } & \multicolumn{4}{|c|}{ Seore } & & $\mathrm{cm}$ & \multicolumn{2}{|c|}{$m m$} \\
\hline \multicolumn{11}{|c|}{ Iowa } \\
\hline Amsoy $71(\mathrm{~A})$ & 56 & 126 & 1.4 & 1.0 & 1.0 & 1.0 & 2.2 & 49 & 72 & 34 \\
\hline PI424001 (PI) & 41 & 90 & 4.8 & 2.0 & 2.0 & 3.0 & 5.0 & 46 & 53 & 18 \\
\hline $\mathbf{F}_{1}$ & 46 & 105 & 4.2 & 2.0 & 2.0 & 1.5 & 4.0 & 85 & 65 & 22 \\
\hline $\bar{x}$ & 48 & 107 & 3.5 & 1.7 & 1.7 & 1.8 & 3.7 & 60 & 63 & 25 \\
\hline \multicolumn{11}{|c|}{ Puerto Rico-Lighted } \\
\hline A & 47 & 100 & 2.4 & 1.0 & 1.0 & & 1.0 & & 124 & 84 \\
\hline PI & 40 & 80 & 5.0 & 2.5 & 2.0 & & 5.0 & & 67 & 28 \\
\hline $\mathbf{F}_{1}$ & 48 & 92 & 5.0 & 1.5 & 1.0 & & 4.0 & & 84 & 44 \\
\hline$\overline{\mathrm{x}}$ & 43 & 91 & 4.1 & 1.5 & 1.3 & & 3.3 & & 92 & 52 \\
\hline \multicolumn{11}{|c|}{ Puerto Rico-Unlighted } \\
\hline A & 40 & 100 & 1.5 & 1.0 & 1.0 & 1.0 & 1.0 & 52 & 99 & 62 \\
\hline PI & 30 & 78 & 4.9 & 2.0 & 2.0 & 2.0 & 5.0 & 68 & 44 & 13 \\
\hline$F_{I}$ & 32 & 82 & 4.2 & 2.0 & 2.0 & 3.0 & 4.4 & 63 & 68 & 34 \\
\hline $\bar{x}$ & 34 & 87 & 3.5 & 1.7 & 1.7 & 2.0 & 3.5 & 61 & 70 & 36 \\
\hline $\mathrm{S}_{\mathrm{x}}$ & 1 & 1 & NS & NS & NS & NS & NS & NS & 2 & 2 \\
\hline
\end{tabular}

Lodging: $1=$ plant erect to $5=$ plant prostrate: Defoliation: $1=$ complete leaf loss at maturity to $2=$ no defoliation; Shattering: $1=$ no shattering to $2=$ shattering; Vining. $1=$ main stem prominent to $3=$ no apparent main stem; Agronomic type: $1=$ highly desirable to $5=$ tundesirable. 
TABLE 3.-Mean agronomic performance, seed composition and fatty acids of Century and PIse6581, and their reciprocal $F_{1}$ hybrids averaged over three environments

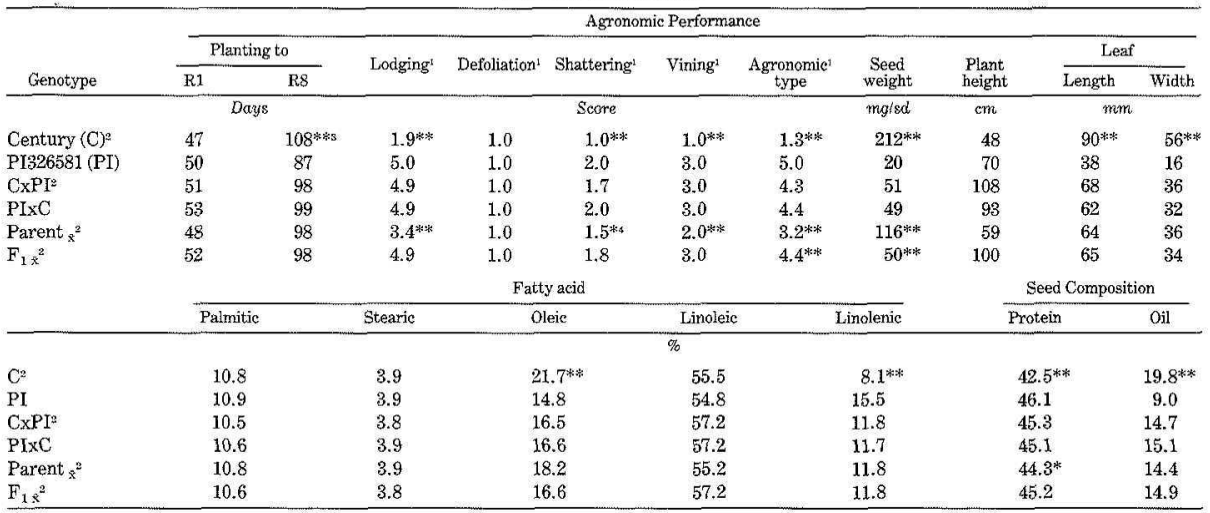

${ }^{1}$ Lodging: $1=$ plant erect to $5=$ plant prostrate; Defoliation: $1=$ eomplete leaf loss at maturity to $2=$ no defoliation; Shattering: $1=$ no shattering to 2 =shattering; Vining: 1=main stem prominent to 3 -no apparent main stem; Agronomic type: 1-highly desirable to $5=$ undesirable.

2 Significant differences between the G. max and $G$. soja parent based on a $t$-test. Reciprocal $F_{1}$ 's were not statistically different based on a $t$-test. Means of the parents which were significantly different from the $F_{1}$ means based on a $t$-test. $F_{1}$ means significantly different from parent means were compared with the PI parent by a $t$-test.

${ }^{3}$ Significant at the 0.01 probability level.

${ }^{4}$ Significant at the 0.05 probability level. 
TABLE 4.-Mean agronomic performance, seed composition and fatty acids of Amsoy 71 and PI424001, and their reciprocal $F_{1}$ hybrids averaged

over three environments

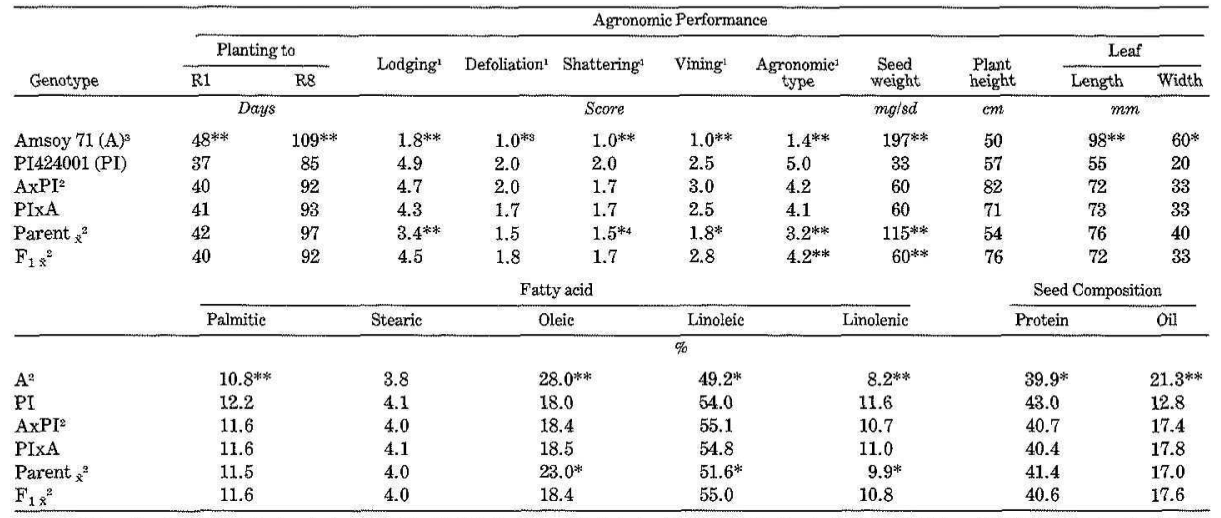

${ }^{1}$ Lodging: $1=$ plant erect to $5=$ plant prostrate; Defoliation: $1=$ complete leaf loss at maturity to $2=$ no defoliation; Shattering: $1=$ no shattering

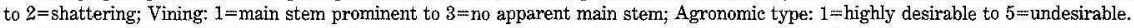

2 Significant differences between the $G$. max and $G$. soja parent based on a $t$-test. Reciprocal $F_{1}$ 's were not statistically different based on a t-test. Means of the parents which were significantly different from the $F_{1}$ means based on a $t$-test. $F_{1}$ means significantly different from parent means were compared with the PI parent by a $t$-test.

s Significant at the 0.01 probability level.

${ }^{4}$ Signifieant at the 0.05 probability level. 
Mean values of agronomic traits, seed composition, and fatty acids of reciprocal $\mathrm{F}_{1}$ hybrids were not significantly different from each other.

The type of gene action varied among traits and included additive, dominance, and partial dominance (tables 3 and 4). Additive gene action was found in both crosses for number of days to $R 8$ and for leaf length and width. In the cross Amsoy 71 x PI424001, additive gene action was observed for number of days to R1. Dominance of the $G$. soja parent was observed in both crosses for lodging, shattering, and vining and for the cross Amsoy $71 \times$ PI424001 for defoliation. Partial dominance of the wild parent was observed for agronomic type and seed weight for both crosses. No statistically significant differences were observed between the means of the $\mathrm{F}_{1}$ and $\mathrm{F}_{2}$ generations (data not shown). However, for lodging, shattering, and vining where dominance gene action was observed in the $F_{1}$ generation, the mean values in the $F_{2}$ generation were smaller than for the $\mathrm{F}_{1}$.

For seed composition traits, both crosses exhibited additive gene action for the percentage of oil (tables 3 and 4). Differences between crosses were observed in the mode of inheritance of the other chemical traits studied. In the cross Century x PI326581, additive gene action was observed for the percentage of oleic and of linolenic acids in the oil, and dominance of the $G$. soja parent was observed for protein percentage. In the cross Amsoy $71 \times$ PI424001, dominance of the wild parent was observed for the percentages of oleic and linolenic acids, and additive gene action was observed for protein percentage. In the latter cross, additive gene action was found for the percentage of palmitic acid and dominance for the percentage of linoleic acid.

The results of our study indicated that it is possible to use tropical environments to evaluate for agronomic traits of genotypes of $G$. max and $G$. soja and their $F_{1}$ hybrids. The relative performance among genotypes within environments was similar, suggesting that the statistical significance of the genotype $x$ environment interaction was the result of changes in the magnitude of differences among genotypes, rather than changes in the relative ranking of the genotypes across environments.

The mean agronomic performance, seed composition, and fatty acids in the oil of reciprocal $F_{1}$ 's indieated that cytoplasmic effects were not important in interspecific crosses between $G$. max and $G$. soja. These observations agree with the report of Weber (13) who did not find any cytoplasmic effects in four traits measured in one $G$. max $\times$ G. soja cross. For breeders considering the transfer of useful characters from $G$. soja to $G$. max, either species may be used as female parents to obtain $\mathrm{F}_{1}$ seed.

The type of gene action controlling individual characters in our study was compared with that reported by other workers. Variation in the 
type of gene action controlling characters of $G$. soja $\times$ G. max crosses has been reported by Fukuda (6), Ting (12), Weber (13), and Williams (14). Additive gene action was observed for maturity date in our study and by Weber (13), and Williams (14). Dominance of the wild parent for vining was found in our study and also by Williams (14). For seed weight, partial dominance of the wild parent was observed in our study using an arithmetic scale and calculating the arithmetic mean. These observations were in agreement with the results of Ting (12) and Weber (13) but differ from the observations by Fukuda (12). The three authors used arithmetic scales, and Ting (12) also calculated the geometric mean. When Weber (13) transformed the data to a logarithmic scale, however, he observed additive gene action, which was in agreement with the results of Fukuda (6). For agronomic type, our data indicated partial dominance of the $G$. soja parent, Ting (12) reported additive gene action, and Williams (14) observed dominance of the wild parent. Of the chemical traits evaluated in our work, only protein and oil percentage were evaluated previously. For oil percentage, the results of our study and those of Weber (13), and Williams (14) indicated the presence of additive gene action. For protein percentage, additive gene action was observed in our study in one of the crosses and dominance of the $G$. soja parent for the other cross. Weber (13) reported partial dominance of the high-protein $G$. soja parent, and Williams (14) observed dominance of the high-protein $G$. soja parent. The differences observed among studies for the inheritance of some of the traits seem to be due to different plant accessions of $G$. max and $G$. soja that were used. In the case of the variation observed among studies for the inheritance of seed size, a scale effect may also be present.

\section{RESUMEN}

La herencia de caracteres agronómicos y la composición química de la semilla en cruzamientos de Glycine max x Glycine soja

Los objetivos de este estudio fueron evaluar los caracteres agronómicos de $G$. max, $G$. soja y sus híbridos $F_{1}$ en ambientes tropical y templado; determinar si en los cruzamientos recíprocos entre estas dos especies hay efectos citoplasmáticos para los caracteres agronómicos y de composición química de la semilla; y evaluar el tipo de acción génica que controla la herencia de los caracteres en estos cruzamientos. Se realizaron cruces recíprocos entre 'Century' y P1326581, y entre 'Amsoy 71' y PI424001. Treinta plantas de cada uno de los padres y 50 plantas $F_{1}$ de cada cruzamiento se sembraron en dos ambientes en Puerto Rico y uno en lowa. Se evaluaron los siguientes caracteres: etapa R1 y R8, tamaño de la hoja, dehiscencia de las vainas, pérdida de hojas, presencia de guías, acamado, tipo agronómico, altura de la planta, peso de 100 semillas, porcentaje de aceite y proteína en la semilla, y porcentaje de los ácidos palmítico, esteárico, oleico, linoleico y linolénico en el aceife. No se observaron diferencias significativas 
entre ambientes en siete de los 11 caracteres agronómicos evaluados en los dos cruzamientos. El comportamiento relativo de los genotipos para los caracteres evaluados en lowa y Puerto Rico fue similar, lo que indica que es posible usar localidades tropicales para evaluar la progenie de cruzamientos interespecíficos. En cada uno de los dos cruces y para todos los caracteres evaluados, no se observaron diferencias significativas entre las plantas $F_{1}$ obtenidas de los cruzamientos recíprocos, lo que indica que los efectos citoplasmáticos no fueron de importancia. Los tipos de acción génica que se observaron en la herencia de los caracteres evaluados fueron aditivos, de dominancia $y$ de dominancia parcial.

\section{LITERATURE CITED}

1. Ahmad, Q. N., E. J. Britten and D. E. Byth, 1977. Inversion bridges and meiotic behavior in species hybrids of soybeans. J. Hered. 68 : $360-64$.

2. Bravo, J. A., W. R. Fehr and S. R. de Cianzio, 1980. Use of pod width for indirect seleetion of seed weight in soybeans. Crop Sci. 20: 507-10.

3. Cianzio, S. R. de, J. F. Cavins and W. R. Fehr, 1985. Protein and oil percentage of temperate soybean genotypes evaluated in tropical environments. Crop Sci. 25: 602 06.

4. - S. J. Frank and W. R. Fehr, 1982. Seed width to pod width ratio for identification of green soybean pods that have attained maximum length and width, Crop Sci. 22 : $463-66$.

5. Fehr, W. R. and C. E. Caviness, 1977, Stages of soybean development. Iowa Agric. Home Econ. Exp. Stn., Iowa Coop. Ext. Serv. Spec. Rep. 80.

6. Fulada, Y., 1983. Cytogenetical studies on the wild and cultivated Manchurian soybeans (Glyeine L.). Jpn. J. Bot. 6: 489-506.

7. Harlan, J. R. and J. M. J. De Wet, 1971. Toward a rational classifieation of cultivated plants. Taxon 20: 509-17.

8. Hawkins, S. E., W. R. Fehr, E. G. Hammond and S. R. de Cianzio, 1983. Use of tropieal environments in breeding for oil composition of suybean genotypes adapted to temperate climates. Crop Sci. 23: 897-99.

9. Palmer, R. G. and P. N. Mascia, 1980. Genetics and ultrastructure of a cytoplasmically inherited yellow mutant in soybeans. Geneties 95: 985-1000.

10. Shoemaker, R. C., A. M. Cody and R. G. Palmer, 1984. Characterization of a cytoplasmically inherited yellow foliar mutant $\left(e y t-Y_{3}\right)$ in soybean. Theor. Appl. Genet. 69; $279-84$.

11. Terao, H., 1918. Matemal inheritance in the soybean. Am, Nat, 52:51-6.

12. Ting, C. L., 1946. Genetic studies on the wild and cultivated soybeans. J. Am. Soc. Agron. 38: 381-93.

13. Weber, C. R., 1950. Inheritance and interrelation of some agronomic and chemical characters in an interspecific cross in soybeans, Glycine max x G. ussuriensis. Iowa Agric. Exp. Stn. Res. Bull. 374.

14. Williams, L. F., 1948. Inheritance in a species cross in the soybean. Geneties 33: $181-32$, 
